\title{
Production of galacto-oligosaccharides by commercial preparates of fungal $\beta$-galactosidase
}

\author{
Silvia Tokošová, Helena Hronská, Michal Rosenberg \\ Institute of Biotechnology and Food Science, Faculty of Chemical and Food Technology, \\ Slovak University of Technology, Radlinského 9, 81237 Bratislava, Slovak Republic \\ helena.hronska@stuba.sk
}

\begin{abstract}
Three different fungal $\beta$-galactosidases, from three commercial sources, were studied for their capacity to produce galacto-oligosaccharides by trans-galactosylation from lactose. The enzymes were investigated in a soluble form for the GOS production at two concentrations of lactose $(10 \%$ and $30 \%$ $\mathrm{w} / \mathrm{w})$. The maximum of GOS concentration $\left(70.9 \mathrm{~g} \cdot \mathrm{L}^{-1}\right)$ was obtained at $30 \%$ of the initial lactose $(\mathrm{pH} 4.5$, temperature $\left.30{ }^{\circ} \mathrm{C}\right)$ in the second hour of enzyme reaction. The GOS yield $(24 \% \mathrm{w} / \mathrm{w})$ was not significantly affected by the process of immobilisation in comparison with the free enzyme preparation ( $22 \% \mathrm{w} / \mathrm{w})$, but time to obtain a maximal GOS concentration was prolonged. Galacto-oligosaccharides were effectively produced by immobilised $\beta$-galactosidase in the 15 repeated batch runs of $30 \%(\mathrm{w} / \mathrm{w})$ of lactose as the substrate.
\end{abstract}

Key words: $\beta$-galactosidase, galacto-oligosaccharides, immobilisation

\section{Introduction}

$\beta$-galactosidase (EC 3.3.1.23), also known as the lactase, is one of the most important enzymes used in the food industry, which offers nutritional, technological and environmental applications (Torres et al., 2010). This enzyme catalyses hydrolytic and trans-glycosylation reactions and shifts the equilibrium of the reaction that depends on the aqueous systems and concentration of saccharides in reaction mixture. Hydrolytic activity of this enzyme is important for applications in the food industry in reducing the lactose content in milk, and increases the solubility and sweetness in dairy products. The lactose is a disaccharide that is produced as a dairy by-product in enormous quantities, and in particular, the production of the lactose from whey has increased exponentially in recent years due to the high demand of consumers (Otieno, 2010). Whey with content of lactose is a serious enviromental problem, and also food with lactose, which cannot be consumed by lactose-intolerant people. This disaccharide can be hydrolysed in both cases by the action of $\beta$-galactosidase to monosaccharides (glucose and galactose) and GOS which are formed simultaneously (Princely et al., 2013).

In last years, consumer interest in the relationship between diet and health has increased the demand for information about functional foods. These foods can provide specific health benefits and reduce risk of human disease. Significant attention is devoted to a specific type of dietary carbohydrates, non-digestible oligosaccharides (NDO), as the functional components of foods (Mussatto and Mancilha, 2007).
Oligosaccharides (OS) are defined as glycosides with a different degree of polymerisation. In this group belong lactulose, raffinose, maltooligosaccharides, inulin, fructo-oligosaccharides (FOS) and galactooligosaccharides (GOS) (Manucci, 2009). NDOs are useful as prebiotics, components that selectively stimulate the growth of bacteria, especially of the genera Bifidobacterium and Lactobacillus-probiotics (Adamczak et al., 2009). The most common NDOs used as food ingredients are galacto-oligosaccharides and fructo-oligosaccharides. The system probiotics/prebiotics is used as a supplement to specialised foods due to their wide variety of health benefits including the reduction of the risk of colon cancer, improved liver function, lipid metabolism and intestinal health and reduction in cholesterol (Hingu and Shah, 2013; Otieno et al., 2010).

The prebiotics galacto-oligosaccharides are the short-chain carbohydrates that are composed of 2-20 molecules of galactose and one molecule of glucose (Torres et al., 2010). Synthesis of GOS is performed by the enzymatic hydrolysis catalysed by $\beta$-galactosidase. For the production of GOS, substrates with a high concentration of lactose, especially milk, whey or a mixture of both are necessary (Martins et al., 2011). GOS are commonly produced by $\beta$-galactosidase in either free or immobilised form. The length of the galacto-oligosaccharides chain generated by enzymatic reaction depends on the lactose concentration, source and concentration of enzyme, $\mathrm{pH}$ and temperature of reaction mixture (Mahoney, 1998).

The production of galacto-oligosaccharides with immobilised enzymes (or microorganisms) provides 
many advantages compared with the free enzyme form, e.g. reusability of the biocatalyst, continuous operations, controlled product formation and simplified and efficient processing. Many different techniques and carriers have been reported for the immobilisation of $\beta$-galactosidase, including covalent binding, adsorption, entrapment and encapsulation. The LentiKats technology is a type of immobilisation method in which enzymes or cells are entrapped in lens-shaped PVA hydrogel capsules, called LentiKats (diameter 3-4 mm, thickness 200-400 $\mu \mathrm{m}$ ). Polyvinyl alcohol gel has several advantages in comparison with other carriers such as a low biodegradability, low toxicity, excellent mechanical, and long-term stability (Grosova 2009; Zajkoska et al. 2015).

The production of GOS by immobilised enzymes was studied with $\beta$-galactosidase immobilised in cotton cloth (Albayrak et al. 2002), ion-exchange resins, calcium alginate ( $\mathrm{Li}$ et al. 2008), polysiloxane-polyvinyl alcohol (Neri et al. 2009), and glyoxyl-agarose gel (Huerta 2011).

The aim of our study is to describe the galactooligosaccharides synthesis at various temperatures and by different commercial preparates of fungal $\beta$-galactosidase. The selected enzyme sample was immobilised in PVA hydrogel and further used in repeated batch trans-galactosylations with lactose as the substrate.

\section{Experimental}

\section{Materials and methods}

\section{Materials}

Three commercial preparates of fungal $\beta$-galactosidase were used in this work: $\beta$-galactosidase 96049 (Fluka, Switzerland), $\beta$-galactosidase G5160 (SigmaAldrich, Germany) and $\beta$-galactosidase, sample B was kindly donated by the company Brenntag Slovakia Co. (Pezinok, Slovakia). All enzyme preparations were stored at $4{ }^{\circ} \mathrm{C}$ and remained fully active throughout the work.

Polyvinylalcohol (PVA) and polyethylene glycol was provided by LentiKat's Inc. (Prague, Czech Republic). All other reagents were of analytical grade from different sources.

\section{Enzyme assay}

The hydrolytic activity of $\beta$-galactosidase in the free and immobilised form was determined by using $30 \%(\mathrm{w} / \mathrm{w})$ lactose in $0.1 \mathrm{~mol} \cdot \mathrm{L}^{-1}$ acetate buffer (50 mL; pH 4.5) as substrate. The hydrolytic reaction was started by adding the soluble enzyme preparation $(150 \mu \mathrm{L}$ of enzyme solution, $0.1 \mathrm{~g}$ of enzyme powder dissolved in $1 \mathrm{~mL}$ of acetate buffer,
$\mathrm{pH} 4.5$ ) or immobilised enzyme ( $0.5 \mathrm{~g}$ of immobilised particles). The enzyme reaction was carried out at $30{ }^{\circ} \mathrm{C}$ with agitation $(250 \mathrm{rpm})$. The samples were taken at regular time intervals and the samples with free enzyme were inactivated by boiling (5 min). Analysis of the samples was carried out by HPLC and hydrolytic activity was calculated on the basis of glucose concentration.

One unit of the enzyme activity was defined as the amount of enzymes capable of generating one micromole of glucose per 15 min under our experimental conditions. Specific activity of the free enzyme was calculated as $\mathrm{U}$ per $\mathrm{mg}$ of free enzyme $\left[\mathrm{U} \cdot \mathrm{mg}^{-1}\right]$. Specific activity of the immobilised enzyme was calculated as $\mathrm{U}$ per $\mathrm{g}$ of LentiKats ${ }^{\circledR}$ $\left[\mathrm{U} \cdot \mathrm{g}^{-1}\right]$.

All experiments were performed in duplicate and the given data are the averages of both measurements.

\section{Synthesis of galacto-oligosaccharides}

The reaction was carried out in $250 \mathrm{~mL}$ flasks with a work volume $50 \mathrm{~mL}$ of lactose $(10 \%$ and $30 \%$ $\mathrm{w} / \mathrm{w})$ at $30^{\circ} \mathrm{C}$ and with agitation $(250 \mathrm{rpm})$. Transgalactosylation was started by adding an appropriate amount of $\beta$-galactosidase. The samples were taken at regular time intervals and the samples with the free enzyme were inactivated by boiling ( $5 \mathrm{~min}$ ). Analysis of the samples was carried out by HPLC. The production of GOS was characterised by yield of GOS. $\mathrm{Y}_{(\mathrm{GOS})} \%$ is defined as a maximum of total GOS obtained during the synthesis per unit mass of initial lactose.

\section{Immobilisation of $\boldsymbol{\beta}$-galactosidase}

$\beta$-galactosidase $\mathrm{B}$ was immobilised according to the manufacturer's instructions (www.lentikats.eu). PVA gel solution was composed of PVA (10 g), polyethylene glycol $(6 \mathrm{~g})$ and $79 \mathrm{~mL}$ of distilled water. The gel was melted for $20 \mathrm{~min}$ at $95{ }^{\circ} \mathrm{C}$ max. in a water bath and then cooled to $40^{\circ} \mathrm{C}$, when $5 \mathrm{~mL}$ of enzyme solution ( $1 \mathrm{~g}$ of powder enzyme preparation was dissolved in $5 \mathrm{ml}$ of distilled water) was added to PVA gel dropwise with constant stirring. The particles formed by the LentiPrinter device were dried for $45 \mathrm{~min}$ in an airflow cabinet at $40^{\circ} \mathrm{C}$. Then they were re-swelled in a stabilising solution $\left(0.1 \mathrm{M} \mathrm{Na}_{2} \mathrm{SO}_{4}\right)$ for 30-40 $\mathrm{min}$, and after washing with an acetate buffer, were either stored at $4^{\circ} \mathrm{C}$ in an acetate buffer $(0.1 \mathrm{M}$; $\mathrm{pH} 4.5$ ) or directly used for biocatalysis.

\section{Analysis}

Lactose and products of GOS synthesis (glucose, galactose and GOS) were determined by high performance liquid chromatography (HPLC). Fig. 1 shows the typical chromatogram of a sample after 


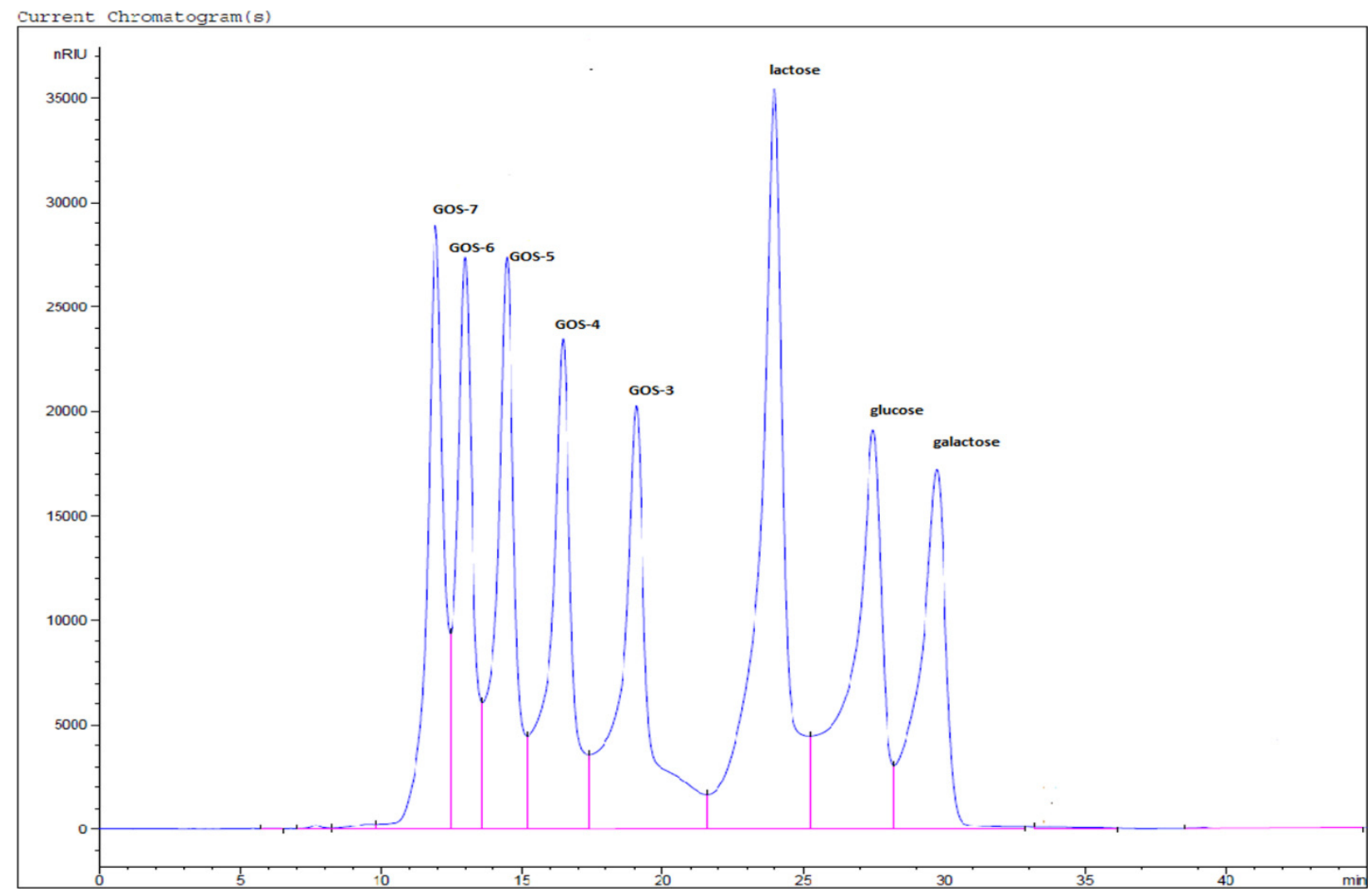

Fig. 1. Chromatogram of galacto-oligosaccharides by HPLC with RI detector and BP-200 $\mathrm{Ag}^{+}$form column.

the trans-galactosylation reaction. The analysis was performed using the column Benson polymeric ${ }^{\mathrm{TM}}$ (Carbohydrate Column, $\mathrm{Ag}^{+}$form, BP-200), as a detector was used differential refractometer Knauer RI (Knauer, Germany). The mobile phase was filtered in distilled water and the flow rate was kept constant at $0.4 \mathrm{~mL} \cdot \mathrm{min}^{-1}$. The column temperature was kept at $80^{\circ} \mathrm{C}$.

\section{Results and discussion}

\section{Effect of enzyme and lactose concentration on GOS synthesis}

Hydrolytic and trans-galactosylation activities of $\beta$-galactosidases strongly depend on their origin and also their reaction conditions. $\beta$-galactosidases from Aspergillus oryzae can produce the highest yields of GOS in comparison with other microbial strains, e.g. Aspergillus niger, Kluyveromyces lactis or Kluyveromyces fragilis (Guerrero et al., 2015).

Based on the previous published results, we studied and compared the synthesis of galactooligosaccharides by selected commercial preparat of $\beta$-galactosidase isolated from different strains of Aspergillus oryzae.

To determine the influence of the enzyme origin on the yield of GOS and on the hydrolytic activity, experiments were performed at $30 \%$ of the initial lactose concentration $\left(\mathrm{pH} 4.5\right.$, temperature $30{ }^{\circ} \mathrm{C}$ ) with three different $\beta$-galactosidases. As shown Fig. 2 the maximal hydrolytic activity was observed for the enzyme $\mathrm{B}\left(15.1 \mathrm{U} \cdot \mathrm{mg}^{-1}\right)$ compared with enzyme $\mathrm{S}\left(7.6 \mathrm{U} \cdot \mathrm{mg}^{-1}\right)$ and $\mathrm{F}\left(8.1 \mathrm{U} \cdot \mathrm{mg}^{-1}\right)$. The largest yields of galacto-oligosaccharides were produced in the second hour of the trans-galactosylations, sample S $18 \%(\mathrm{w} / \mathrm{w})$; sample F $19 \%(\mathrm{w} / \mathrm{w})$ and sample B $22.4 \%(w / w)$. After this time, unwanted secondary hydrolysis of GOS started to result in an increase of concentration of monosaccharides in the reaction mixture. The time course of the typical trans-galactosylation reaction is presented in Fig. 3 . It is possible to observe the maximal concentration of GOS $\left(70.9 \mathrm{~g} \cdot \mathrm{L}^{-1}\right)$ in the second hour of the reaction, and after this point the galacto-oligosaccharides starts to be hydrolysed to monosaccharides. The concentration of GOS in eighth hour was only $56.6 \mathrm{~g} \cdot \mathrm{L}^{-1}$ due to the secondary hydrolysis of GOS. The onset and progress of the secondary hydrolysis can be affected by the amounts of enzyme in the reaction mixture (Guerrero et al., 2015).

The initial lactose concentration and source of enzyme significantly affected the profile and the amount of galacto-oligosaccharides (MartinezVillaluenga, 2008). The profile of GOS after $2 \mathrm{~h}$ 


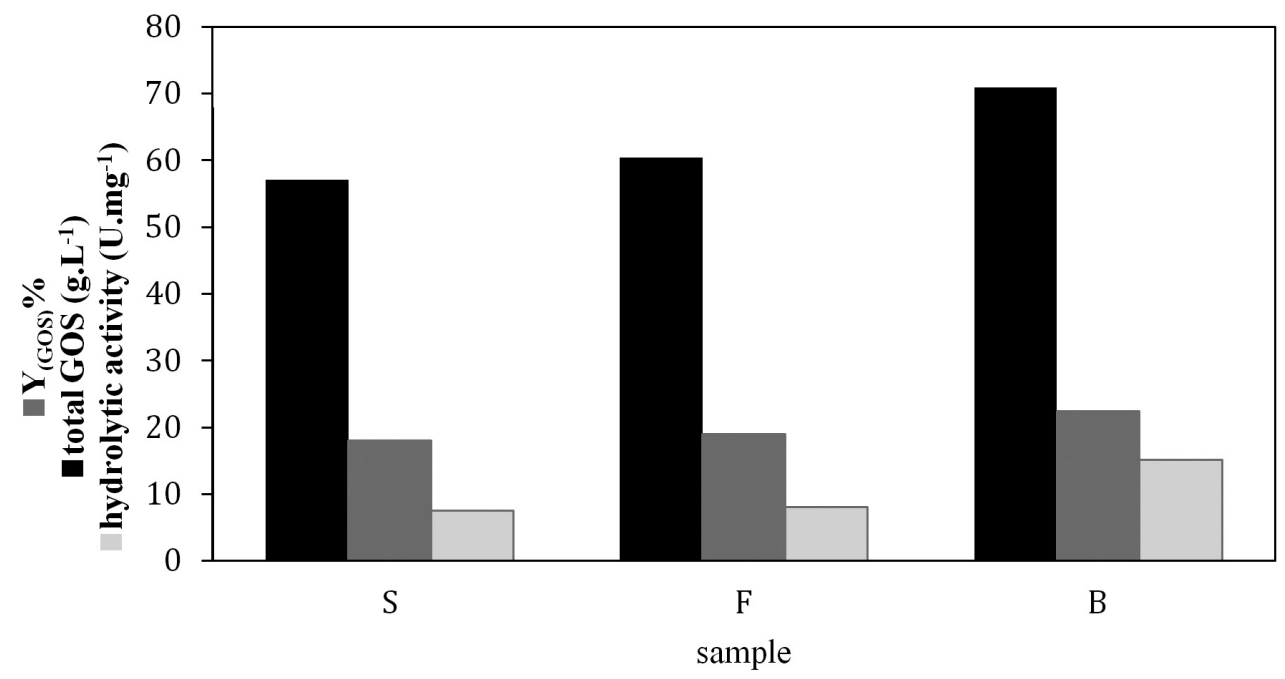

Fig. 2. Hydrolytic activity and production of GOS by commercial enzyme preparations.

Reaction conditions: lactose $30 \%$ (50 ml in acetate buffer $\mathrm{pH} 4.5$ ), $150 \mu \mathrm{l}$ of enzyme preparation, temperature $30^{\circ} \mathrm{C}$, slightly mixing.

${ }^{*} \mathrm{Y}_{(\mathrm{GOS})} \%$ - maximum of total GOS obtained during the synthesis per unit mass of initial lactose.

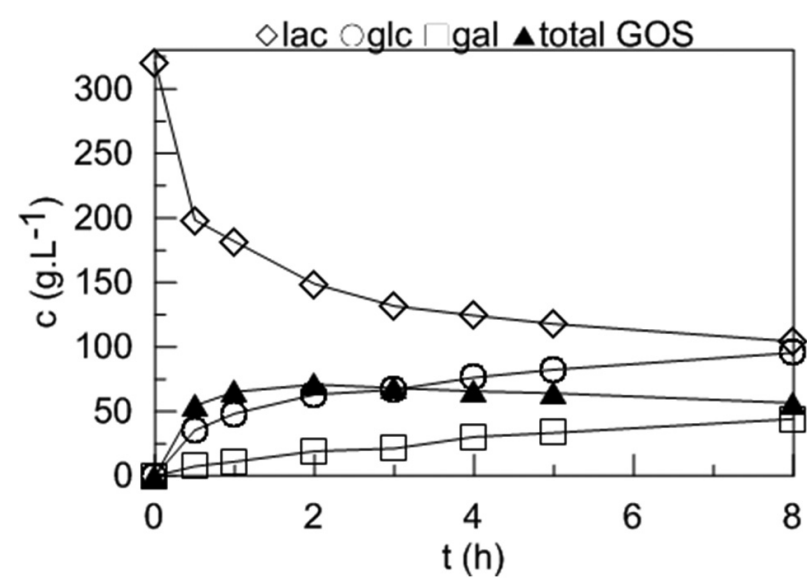

Fig. 3. Kinetics of GOS synthesis catalysed by free $\beta$-galactosidase sample B.

Reaction conditions: lactose $30 \%(50 \mathrm{ml}$ in acetate buffer $\mathrm{pH} 4.5$ ), $150 \mu \mathrm{l}$ of enzyme preparation, temperature $30^{\circ} \mathrm{C}$, slightly mixing. of incubation in the presence of three samples of $\beta$-galactosidases at different initial lactose concentration $(10 \%$ and $30 \% \mathrm{w} / \mathrm{w})$ is shown in Table 1 . It was found that the amount of GOS increased with increasing lactose concentration from $10 \%$ to $30 \%$, at which point yield of GOS reached $22.4 \%(\mathrm{w} / \mathrm{w})$. The rate of trans-galactosylation is lower at low lactose concentration than that of hydrolysis, where a higher amount of glucose and galactose and a lower concentration of GOS are formed.

As we can see in Table 1, GOS-3 dominated over the other types of GOS formed during the transgalactosylations. In the case of sample $\mathrm{F}$ and sample $\mathrm{S}$, close to $80 \%$ of all GOS was in the form of GOS-3 and around $98 \%$ in the form of GOS-3 plus GOS-4. The composition of GOS was somewhat different for sample $\mathrm{B}$, with the proportion of GOS-6 and GOS-5 higher (around $7 \%$ ) and with a lower percentage of GOS-3 (around $70 \%$ ) and GOS-3 plus GOS-4 (around $93 \%$ ). Our results are in accordance with data in the literature that relate

Tab. 1. Profiles of GOS at the $2^{\text {nd }}$ hour of trans-galactosylation with enzymes from different sources.

\begin{tabular}{lcllccc}
\hline & $\begin{array}{c}\text { Concentration of lactose } \\
\%(\mathrm{w} / \mathrm{w})\end{array}$ & $\begin{array}{l}\text { GOS 6 } \\
\left(\mathrm{g} \cdot \mathrm{L}^{-1}\right)\end{array}$ & $\begin{array}{c}\text { GOS 5 } \\
\left(\mathrm{g} \cdot \mathrm{L}^{-1}\right)\end{array}$ & $\begin{array}{c}\text { GOS 4 } \\
\left(\mathrm{g} \cdot \mathrm{L}^{-1}\right)\end{array}$ & $\begin{array}{c}\text { GOS 3 } \\
\left(\mathrm{g} \cdot \mathrm{L}^{-1}\right)\end{array}$ & $\begin{array}{c}\text { Total GOS } \\
\left(\mathrm{g} \cdot \mathrm{L}^{-1}\right)\end{array}$ \\
\hline \multirow{2}{*}{ Fluka $(\mathbf{F})$} & 10 & 0 & 0.03 & 1.8 & 9.35 & 11.2 \\
& 30 & 0 & 1.14 & 10.03 & 49.27 & 60.4 \\
\hline \multirow{2}{*}{ Sigma (S) } & 10 & 0 & 0.32 & 2.06 & 9.28 & 11.6 \\
& 30 & 0 & 0.99 & 9.1 & 47.05 & 57.14 \\
\hline \multirow{2}{*}{ Brenntag $(\mathbf{B})$} & 10 & 0 & 0 & 0.9 & 5.6 & 6.5 \\
& 30 & 0.62 & 3.92 & 15.99 & 50.37 & 70.9 \\
\hline
\end{tabular}


the profile of GOS to the origin of the enzyme (Guerrero et al., 2015).

The maximum amount of GOS in our experimental conditions was produced with the sample of $\beta$-galactosidase $B$, where the composition of the different types of GOS was as follows: GOS3 $50.37 \mathrm{~g} \cdot \mathrm{L}^{-1}$, GOS4 $15.99 \mathrm{~g} \cdot \mathrm{L}^{-1}$, GOS5 $3.92 \mathrm{~g} \cdot \mathrm{L}^{-1}$, GOS6 $0.62 \mathrm{~g} \cdot \mathrm{L}^{-1}$.

\section{Immobilisation of $\beta$-galactosidase}

The main reason for enzyme immobilisation is the reusability, extended use and also, very often, a better performance in the bioconversion processes. However, it is generally known that the immobilisation processes cause a decline in the enzyme activity.

The commercial preparation of $\beta$-galactosidase sample B was immobilised to PVA gel in the form LentiKats ${ }^{\circledR}$ according to the procedure described in Materials and Methods. Although the enzyme lost $68 \%$ of its hydrolytic activity after immobilisation (compared with free enzyme), repeated use of immobilisates can compensate this disadvantage of immobilisation. This fact could be connected to both a diffusion barrier of hydrogel for the substrate/product and the changes in enzyme structure induced by the interaction of the enzyme with the hydrogel (Grosova et al., 2009).

The influence of two different amounts of immobilisates $(0.5 \mathrm{~g}$ and $1.0 \mathrm{~g} \mathrm{LKs})$ on a course of trans-galactosylation reactions and the yield of GOS were investigated at $30{ }^{\circ} \mathrm{C}$ in $30 \%(\mathrm{w} / \mathrm{w})$ of lactose as the substrate (Fig. 4). Galacto-oligosaccharides produced by $1 \mathrm{~g}$ of LentiKats ${ }^{\circledR}$ reached a maximal concentration of GOS $\left(61.3 \mathrm{~g} \cdot \mathrm{L}^{-1}\right)$ in the ninth hour of trans-galactosylation, and then started an unwanted secondary hydrolysis of products. On the other hand, better results were obtained by using of $0.5 \mathrm{~g}$ of immobilisates in the reaction mixture. Although the higher concentration of galactooligosaccharides $\left(74.9 \mathrm{~g} \cdot \mathrm{L}^{-1}\right)$ was observed later
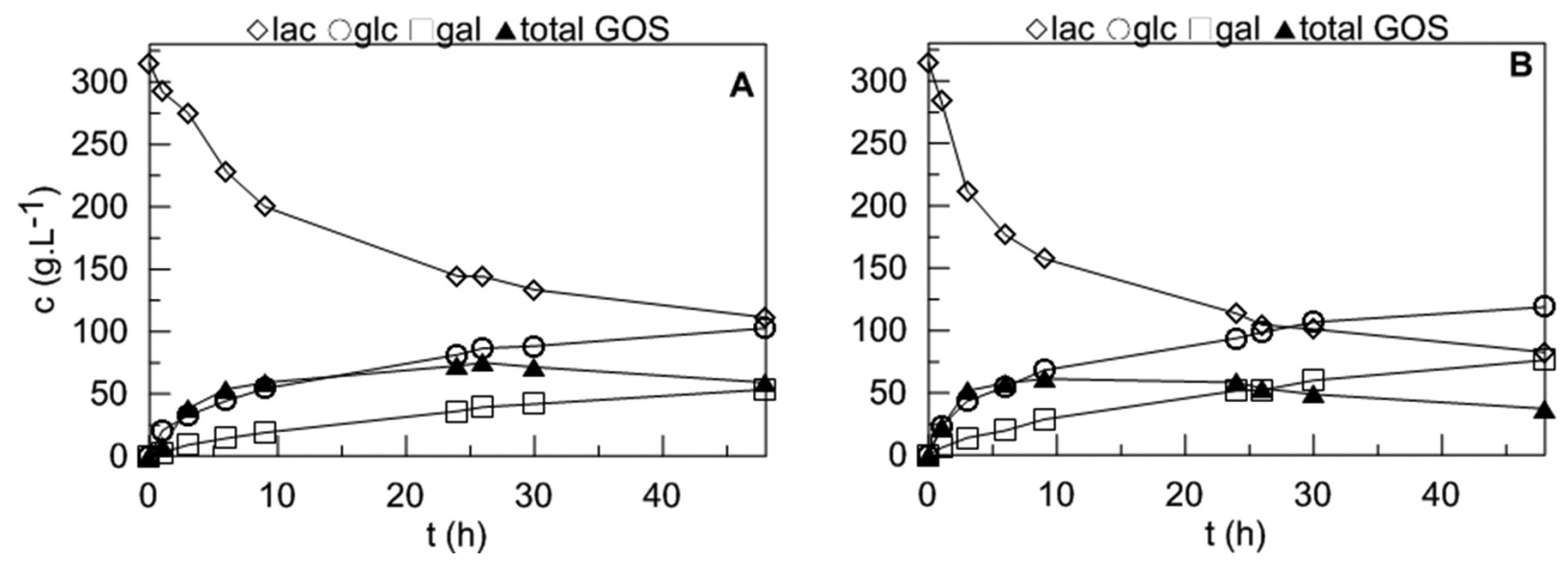

Fig. 4. Trans-galactosylation reaction by immobilised $\beta$-galactosidase: $0.5 \mathrm{~g}(\mathrm{~A}) ; 1 \mathrm{~g} \mathrm{(B)}$.

Conditions of reaction: lactose $30 \%(\mathrm{w} / \mathrm{w})$ in acetate buffer $(\mathrm{pH} 4.5 ; 50 \mathrm{~mL}), 30{ }^{\circ} \mathrm{C}$, moderate mixing.

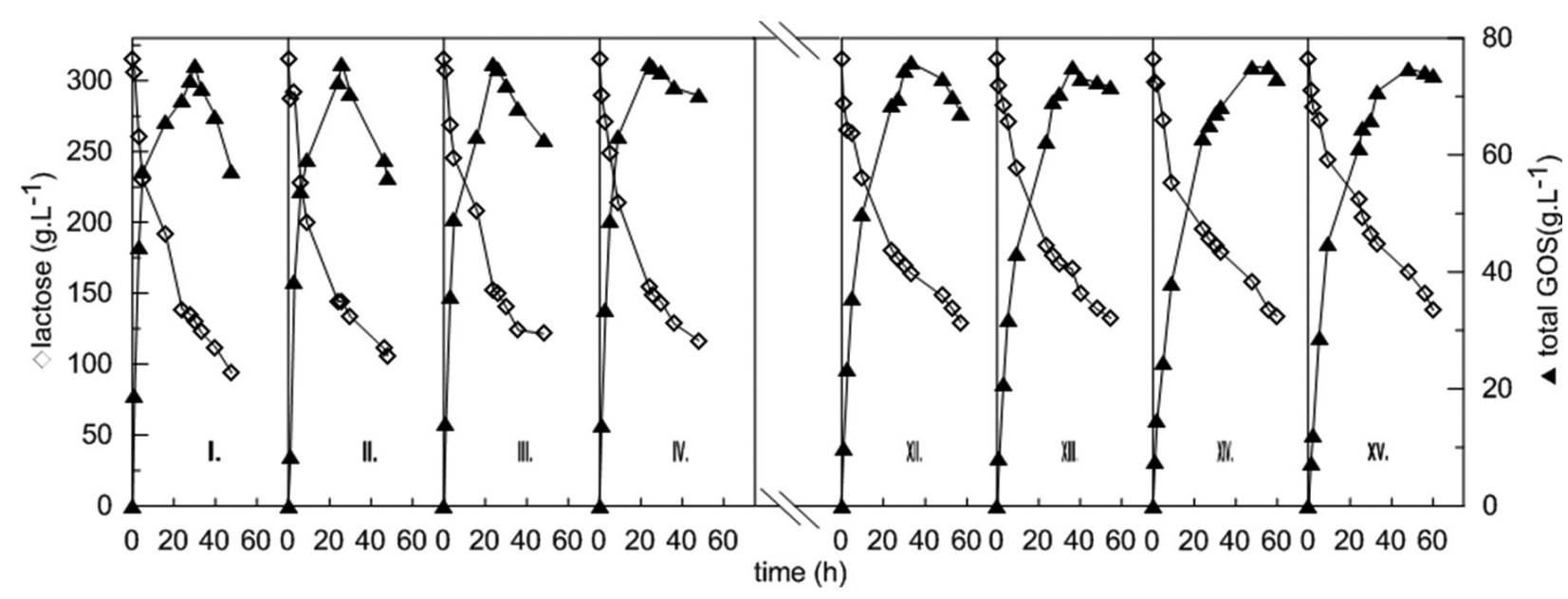

Fig. 5. Repeated batch trans-galactosylations by immobilised $\beta$-galactosidase sample B. Condition of reactions: lactose $30 \%(\mathrm{w} / \mathrm{w})$ in acetate buffer $(\mathrm{pH} 4.5 ; 50 \mathrm{ml}), 0.5 \mathrm{~g}$ of LKs, temperature $30^{\circ} \mathrm{C}$, slightly mixing. 
(in the $26^{\text {th }}$ hour of reaction time) the secondary hydrolysis of products was slow.

Reusability of LentiKats ${ }^{\circledR}$ for GOS production was tested in repeated batch trans-galactosylations by using $0.5 \mathrm{~g}$ of LKs in $50 \mathrm{~mL}$ of $30 \%$ lactose in acetate buffer. After each batch conversion, immobilisates were washed by an acetate buffer and then used for the next run. We performed 15 repeated batches with maximal concentration of GOS around $75 \mathrm{~g} \cdot \mathrm{L}^{-1}$ in every run. Fig. 5 shows that the yields of GOS were still the same value $(24 \% \mathrm{w} / \mathrm{w})$ but the time of trans-galactosylations to achieve this value was prolonged. Our findings were similar to those published in the literature (Albayrak et al., 2002). Immobilised $\beta$-galactosidase is commonly used for lactose hydrolysis, which is shown in various reports, but effective production of GOS by immobilised biocatalysts needs to be investigated (Huerta et al., 2011).

\section{Conclusions}

Galacto-oligosaccharides production and the enzyme activity of three commercial preparates of fungal $\beta$-galactosidase in our experimental condition were investigated. The amount and composition of GOS in the reaction mixture depends on the type and concentration of biocatalyst and substrate concentration as well as on the reaction conditions. The higher production of galacto-oligosaccharides was obtained with $\beta$-galactosidase sample $B$ in free and immobilised form. The enzyme was immobilised by entrapment in PVA lenses. The yields of galacto-oligosaccharides produced by the immobilised enzyme was $24 \%$ compared with the soluble enzyme (22 \%). GOS were effectively produced by immobilised biocatalysts in 15 repeated batch trans-galactosylations in which LentiKats ${ }^{\circledR}$ particles showed high mechanical and operational stability.

\section{Aknowledgements}

This research was supported by a project of the Development of Competence Centre for Research and Development in Molecular Medicine ITMS 26240220071 as well as by the Scientific Grant Agency of the Ministry of Education of the Slovak Republic and the Academy of Sciences, registration number 1/0229/12.

\section{References}

Adamczak M, Charubin D, Bendarski W (2009) Chemical Papers 63(2): 111-116.

Albayrak N, Yang ST (2002) Biotechnology and Bioengineering 77: 9-18.

Grosova Z, Rosenberg M, Gdovin M, Slavikova L, Rebros M (2009) Food Chemistry 116(1): 96-100.

Guerrero C, Vera C, Acevedo F, Illanes A (2015) Journal of Biotechnology 209: 31-40.

Hingu MN, Shah HS (2013) The Microbes 5: ISSN: 23213728 (Online).

Huerta LP, Vera C, Guerrero C, Wilson L, Illanes A (2011) Process Biochemistry 46: 245-252.

Li Z, Xiao M, Lu L, Li Y (2008) Process Biochemistry 43: 896-899.

Mahoney RR (1998) Food Chemistry 63(2): 147-154.

Mannucci F (2009) Dublin Institute of Technology, master thesis.

Martinez-Villaluenga C, Cerdelle-Cobas A, Corzo N, Olano A, Villamiel M (2008) Food Chemistry 107: 258-264.

Martins AR, Manera AP, Monteiro RL, Burkert JFM (2011) Brazilian Journal of Food Technology 14(2): 130-136.

Mussatto SI, Mancilha IM (2007) Carbohydrate Polymers 68: 587-597.

Neri DFM, Balcao VM, Costa RS, Rocha ICAP, Ferreira EMFC, Torres DPM, Rodrigues LRM, Carvalho Jr. LB, Teixeira JA (2009) Food Chemistry 115: 92-99.

Otieno DO (2010) Food Science and Food Safety 9: 471-482.

Princely S, Basha NS, Kirubakaran JJ, Dhanaraju MD (2013) European Journal of Experimental Biology 3: 242-251.

Torres DPM, Goncalves MPF, Teixeira JA, Rodrigues LR (2010) Food Science and Food Safety 9: 438-454.

Zajkoska P, Rosenberg M, Heath R, Malone KJ, Stloukal R, Turner NJ, Rebros M (2015) Applied Microbiology and Biotechnology 99: 1229-1236. 